University of Warwick institutional repository: http://go.warwick.ac.uk/wrap This paper is made available online in accordance with publisher policies. Please scroll down to view the document itself. Please refer to the repository record for this item and our policy information available from the repository home page for further information.

To see the final version of this paper please visit the publisher's website. Access to the published version may require a subscription.

Author(s): Peter Marshall

Article Title: The Other Black Legend: The Henrician Reformation and the Spanish People

Year of publication: 2001

Link to published version: http://dx.doi.org/10.1093/ehr/116.465.31

Publisher statement: This is a pre-copy-editing, author-produced PDF of an article accepted for publication in The English Historical Review following peer review. The definitive publisher-authenticated version Marshall, P. (2001) The Other Black Legend: The Henrician Reformation and the Spanish People. The English Historical Review, Vol. 116, pp. 31-49 is available online at: http://dx.doi.org/10.1093/ehr/116.465.31 


\section{THE OTHER BLACK LEGEND: THE HENRICIAN REFORMATION AND THE SPANISH PEOPLE}

The arrest of two suspicious strangers in the episcopal town of Salisbury in Wiltshire on 25 July 1541 was brought immediately to the attention of the bishop, John Salcot. Together with the local dignitary Charles Bulkeley he examined the suspects, and was sufficiently alarmed by the outcome to despatch the prisoners post-haste to the Council in London, together with a description of the circumstances of their arrest, and a record of their interrogations. Salcot's alacrity in the matter was prompted by the discovery that the two men were Spanish priests, their names Juan Abbad and Pedro Ladron, and that they had arrived in England with the intention 'to perswade the heddes of this countrey to leve theirre error and adhere to the truthe'. In London the prisoners were questioned by Archbishop Cranmer, the bishops of London and Westminster, Edmund Bonner and Thomas Thirlby, as well as by other councillors. At the end of July these forwarded a detailed account of what they had learned to the Council attending upon the King, and in September they supplied an update on the interrogations with a request to know the King's pleasure in the matter. ${ }^{1}$

The encounters between the Spanish priests and the English bishops were characterised by obstinacy on the part of the prisoners, combined with frustration on the part of their interrogators. In fact, this requires some immediate qualification, for one of the two priests, Juan Abbad, was found to be 'a verie simple person' who responded to questions about the pope's primacy with the claim that he 'was unlernyd and woolde not medle therewith'. He protested that he had come with the other priest 'onelie for companye as an olde famyliar of his'. ${ }^{2}$ His companion, Pedro Ladron, was, however, a very different proposition, a young man of unshakeable resolve, who signed himself 'servus servorum Dei'. Bishop Salcot and Archbishop Cranmer in turn found him 'a stowte champion for the bisshop of Rome, and an open impugnator of the kinges majesties title of supremitie'. Thus to both of them he seemed 'lyke a traytorous wreche', 'like an errande traytor', appellations that carried a powerful emotional charge, despite their uncertain legal status in application to one who was not an English subject. Asked why he had left Spain for England, and what doctrine he wished to introduce here, he put forward his opinion that the English had withdrawn from the communion of the faithful by denying the Roman pontiff to be the Vicar of Christ. He defended the papal primacy with reference to Matthew 16 ('Tu es Petrus') and other scriptural texts, and believed it to be vindicated by apostolic

\footnotetext{
${ }^{1}$ The documents pertaining to the case are Salcott and Bulkeley’s letter of 25 July to the Council in London (P[ublic] R[ecord] O[ffice], SP 1/166, fo. 136v; L[etters and] P[apers, Foreign and Domestic, of the Reign of Henry VIII, ed. J. S. Brewer, J. Gairdner, and R. H. Brodie (London 1862-1910)], xvi. 1032(1)); a set of interrogatories in Latin ministered to Ladron in Salisbury (PRO, SP 1/166, fo. 138r; LP, xvi. 1032(2)); a self-justificatory Latin oration composed by Ladron (PRO, SP 1/166, fos 139r-v; $L P$, xvi. 1032(3)); the letter, dated 29 July 1541 of Cranmer and other councillors resident in London to the Council with the king (PRO, SP 1/166, fos 143r-144r (LP, xvi. 1047), quote at fo. 143r); a second letter of 2 Sep. from Cranmer and the Council (PRO, SP 1/167, fos 16r-17r; LP, xvi. 1141). In addition a number of documents were confiscated from the two Spaniards on their arrest: Ladron's certificate of admission to the diaconate (PRO, E 135 6/85); a dispensation for him to be ordained priest in his $23^{\text {rd }}$ year (PRO, E 135 6/87); and letters of capacity granted to Abbad in March 1541 (PRO, SP 1/165, fo. 27r; $L P$, xvi. 630). I have hispanicised the names of the two priests from the English and Latin forms found in the documents. Ladron (the style given in E 135 6/87) usually appears there as Latronensis. ${ }^{2}$ PRO, SP 1/166, fo. 143v; 167, fo. 16r.
} 
succession. In addition to rejecting Henry's royal supremacy over the church, Ladron also condemned the king 'for the dyssolvyng of monasteryes' and for the expulsion of monks and hermits. The pulling down of religious houses seemed to him to represent the conversion of the house of God into a stable. The combined theological learning of the archbishop of Canterbury, and the bishops of London and Westminster, could not disabuse him of these opinions, though Cranmer noted sarcastically that he grounded his arguments 'onelie uppon the olde errours and the lawe canon, which it appearith by his own confession he hathe onelie stoodied and that not past fowre yeres. $^{3}$

Of course, the Council's interest in the two priests went beyond a desire to wean them from their erroneous views. What precisely were they doing in England, who had sent them, and what contacts did they have in the country? Answers on all these points were vague and unsatisfactory. It was clear that they had landed at Dartmouth, and were making their way to London when they were picked up in Salisbury. Ladron's own version was that they had initially taken ship for some unspecified destination, but 'beyng dryven by wether to land in England he presumeth to be sent hither by god, and the good spirite'. The authorities in England were understandably suspicious of this providentialist narrative. Officers were despatched to Southampton, Poole, and other southern ports to search for similar infiltrators, though it seems that none were found. Moreover, repeated interrogations could elicit little more information out of the prisoners 'but that they were addressed hither by god and fortune'. Cranmer was also deeply wary of Ladron's claim to be a secular priest, noting him as one 'whome we take to be a Religious person thoughe himselfe denye the same'. ${ }^{4}$ Whether or not the arrival in England was as fortuitous as Ladron claimed, the sense of divine appointment was clearly at the heart of his mission. In his written apologia, he explained that he had been spurred on to make his journey after some two years reflection on the words of scripture 'exi de patria tua et de cognatione tua'. ${ }^{5}$ Though the text does not appear exactly in this form in the Vulgate, this was clearly a reference to Genesis 12:1, God's injunction to Abraham to 'go from your country and your kindred and your father's house to the land that I will show you'. Quite probably, Ladron had in mind the New Testament reprise of the passage, recited by the proto-martyr Stephen in Acts 7:2-3. Appearing before the Council, did Ladron fashion himself on Stephen before the Sanhedrin? Certainly, when Cranmer threatened him with the full penalties of the treason law, Ladron responded that 'he woolde rather suffre $\mathrm{x}$ deathes then he wolde forsake the truthe'. ${ }^{6}$ Whether it was to be his lot to undergo even one of these is unknown. The last we hear of him is in early September 1541, when still maintaining his opinions, he was committed to the Tower. His more malleable companion remained in Cranmer's custody, and similarly disappeared from history. ${ }^{7}$

In itself, the incident I have described is a fairly trivial one. Though the men came to the attention of the Council, and, most probably, of the King himself, their activities

\footnotetext{
${ }^{3}$ PRO, SP 1/166, fos 136v, 138r, 139r-v, 143r; 167, fo. $16 r$.

${ }^{4} \mathrm{PRO}$, SP $1 / 166$, fo. $143 \mathrm{r}$ ( $L P$, xvi. 1047). The itinerancy of the two priests might suggest that they were friars, though there is no evidence of this in the sources. Cranmer's own detestation of the 'sect' of friars is well-documented: D. MacCulloch, Thomas Cranmer: A Life (New Haven and London, 1996), pp. 143-4.

${ }^{5}$ PRO, SP 1/166, fo. 139 r.

${ }^{6}$ PRO, SP $1 / 166$, fo. $143 \mathrm{v}$.

${ }^{7}$ PRO, SP $1 / 167$, fo. 17 r.
} 
did not directly affect governmental policies at a national or regional level in other than a very minor way. It is not immediately evident that the brief emergence from obscurity of the obdurate Spanish priest, Pedro Ladron, has anything important to tell us about the wider religious and political conditions of either England or Spain in the middle decades of the sixteenth century. Clearly, he was a something of a religious zealot, and it would be easy to dismiss him as a 'crank' or a 'fanatic'. There was, moreover, a distinct element of fantasy about what he hoped to achieve, and it is tempting to imagine him as a prototype Don Quixote, with the 'simple and unlearned' Abbad in the role of Sancho Panza. Yet it would be a mistake to assign to Ladron an automatic marginality to processes of historical explanation. It is not necessary to put him forward as a representative or ordinary figure to acknowledge that his ideas and ideals could not have been formed in a vacuum, and I hope to show that his story opens up a seam of interest and meaning for the historian that runs deeper than the merely anecdotal or picaresque. In this paper I plan to work outwards from the details of the case in order to trace and identify some broader patterns of religious and ethnic conflict in mid sixteenth-century Europe. Placed in its appropriate context, the story of the priests' abortive mission can function in a manner akin to the hinge of a diptych, linking together two sharply contrasting portrayals of religious change in Henrician England, the one a flattering self-portrait, the other a harsh caricature. Viewing these contested versions side-by-side invites us to question some of the familiar paradigms which have informed our views both of the nature of the Henrician Reformation, and of the development of Anglo-Spanish relations in the sixteenth century.

To begin this process it is necessary to look towards the milieu from which the two Spaniards came, to follow their path back across the Bay of Biscay to the coast of northern Spain, and to start searching for the connections between the outlook and preoccupations of the lower Spanish clergy, and the religious changes that were taking place in early Tudor England. From the records of interrogation, and the documents carried by the priests themselves into England, a little can be pieced together about their personal histories in the years before their ill-fated expedition. Both were natives of San Roman, a village a couple of miles to the west of Santander on the Atlantic coastline of northern Spain. ${ }^{8}$ This was in Cantabria, the Castilian province lying between the Basque country to the east and Asturias and Galicia to the west. Then as now, Cantabria was a mountainous region, its inhabitants known as montañeses, highlanders. ${ }^{9}$ But in the first half of the sixteenth century it was also part of Spain's window on the world, an important centre for trade with northern Europe. Along with other north-eastern ports, such as Laredo, Portugalete, Bermeo, Fuenterrabia, San Sebastián and Bilbao, Santander participated in the triangular pattern of trade linking Spain, Flanders, and England, a pattern that particularly

\footnotetext{
${ }^{8}$ San Roman is a common Spanish placename, there being at least 6 other villages across the Peninsula with this title. That the priests originated from the Cantabrian coast, however, seems virtually certain from the details about Ladron's parents recorded in his dispensation to advance to the priesthood: his mother was a native of San Roman, and his father of Hoz de Anero, another village in the close vicinity.

${ }^{9}$ On Cantabria in the $16^{\text {th }}$ century, see J. L. Casado, M. Echegaray, A Rodriguez and M. Vaquerizo, Cantabria a Traves de su Historia: La Crisis del Siglo XVI (Santander, 1979); J. L. Casado Soto, Cantabria en los Siglos XVI y XVII (Santander, 1986). The religious history of the region in the early modern period is covered by J. F. Montes, El Clero en Cantabria en la Edad Moderna (Santander, 1996). A classic study of Cantabrian religious attitudes in a later period is W. A. Christian, Person and God in a Spanish Valley (New York and London, 1972).
} 
involved London and Southampton, but also drew in Exeter, Plymouth, and Dartmouth (Ladron's point of entry to England). Cloth, leather, skins, pewter, lead and wheat all came from England into Spanish markets via the Cantabrian and Basque ports, while iron and wool travelled in the other direction. ${ }^{10}$ A sizeable English merchant community was based in these northern ports, which could be reached by sea from south-west England in less than a week. ${ }^{11}$ Ladron and Abbad thus sprang from a society which knew about England and the English. Indeed, one of the few hard facts about their intentions which the interrogators were able to glean from them in July 1541 was that they had an acquaintance in England, a London-based merchant named Francisco de Guebera, whom they hoped would advance them money. ${ }^{12}$

It seems, however, that Ladron's journey to England did not proceed directly from Cantabria, in either a geographical or intellectual sense. Though Santander, and its satellite parish of San Roman, lay in the diocese of Burgos, both priests seem to have been performing their clerical functions in the diocese of Calahorra, lying some way to the south-east in the Ebro valley of the province of Rioja. It was here in December 1540 that Ladron had been ordained deacon in the appropriately bellicosesounding church of Santa Maria de Victoria. ${ }^{13}$ Calahorra itself was a fairly unprepossessing place. Despite a distinguished past as a centre of Roman rule, it was reported in 1562 to be a town of 'very little authority'. ${ }^{14}$ The population in the 1570 s was just over a thousand, and one historian of early modern Spain has described it as an 'overgrown village'. In the year of Ladron's ordination, the great local excitement was a dispute over the running of bulls in the precincts of the cathedral. ${ }^{15}$ But in one particular way, Calahorra was distinguished in the years the two priests found their way there: it had become one of the leading centres in northern Spain for the detection and punishment of heresy, the seat of the Navarrese tribunal of the Inquisition. This

\footnotetext{
${ }^{10}$ The most useful study of Anglo-Spanish trade in this period is still G. Connell-Smith, Forerunners of Drake: A Study of English Trade with Spain in the Early Tudor Period (London, 1954). See also Casado et al, Cantabria a Traves de su Historia, pp. 85 ff; Casado Soto, Cantabria en los Siglos XVI y XVII, pp. $189 \mathrm{ff}$.

${ }^{11}$ Connell-Smith, Forerunners of Drake, p. 11.

${ }^{12}$ PRO, SP 1/166, fos 136v, 138r (LP, xvi. 1032 (1, 2)). The Spanish presence in England had, however, declined over the first decades of the $16^{\text {th }}$ century; in December 1540 Charles V's ambassador, Chapuys, estimated that there were no more than 6 Spanish merchants resident in London: Connell-Smith, Forerunners of Drake, pp. 16, 130.

${ }^{13}$ PRO, E 135 6/85. There is no record in the English archives of when or where Ladron was ordained priest, though in November 1540 he had acquired a dispensation from Rome to be priested when he reached the age of 23: PRO, E 135 6/87. The church where he was ordained deacon seems likely to be the cathedral of Calahorra, which was dedicated to the Virgin, though in conjunction with the martyrs Emeterio and Celedonio: M. De Lecuona, 'La Catedral de Calahorra: Notas Histórico-Arqueológicas', Berceo, ii, 2 (1947), 65. There is an appropriate symbolism in the fact that in the absence of the diocesan, Ladron was ordained by the bishop of Tripoli, a deputy holding his see 'in partibus infidelium'. Rather less appropriately, at the very time Ladron was on his mission to restore the true faith to England, Protestantism was being introduced into Valladolid by a native of Burgos named Francisco San-Roman. See F. Meyrick, The Church in Spain (London, 1892), p. 390.

${ }^{14} \mathrm{~W}$. Monter, Frontiers of Heresy: The Spanish Inquisition from the Basque Lands to Sicily (Cambridge, 1990), p. 144. Calahorra had been an episcopal seat since the fourth century, though the middle ages witnessed repeated attempts to move the see to the town of Santo Domingo de la Calzada. This was settled by a papal bull of 1232 establishing the diocese of Calahorra and La Calzada. See I. F. Blanco, 'Apuntes sobre la Translacion de la Silla Episcopal de Calahorra', in Calahorra: Bimilenario de su Fundacion: Actas del I Symposium de Historia de Calahorra (1984), pp. 387-9.

${ }^{15}$ M. García Calange, 'Las Instituciones Municipales en la Ciudad de Calahorra en el Siglo XVII', in Calahorra: Bimilenario de su Fundacion, p. 395; W. J. Callahan, Church, Politics and Society in Spain, 1750-1847 (Cambridge, MA, 1984), p. 6; P. Gutiérrez Achútegui, Historia de la muy noble antigua y leal ciudad de Calahorra ( $2^{\text {nd }}$ ed. Logroño, 1981), 117.
} 
had come about through accident rather than design. When French armies invaded Navarre in May 1521, the tribunal fled westwards and came to a halt in Calahorra, the nearest episcopal town. It was to remain there, despite complaints that the town was remote and could not provide the requisite legal and theological expertise, until 1570 when it relocated to the larger Riojan town of Logroño. Throughout the middle decades of the century, the Inquisition at Calahorra exercised jurisdiction over Navarre, parts of Old Castile, and the Basque provinces, including the important trading ports of Bilbao and San Sebastián. In an administrative if not a geographical sense, then, Calahorra was in the front-line as fears intensified over the introduction of 'Lutheranism' into Spain by foreign merchants trading in the Biscayan ports. In early 1539 the Calahorran Inquisition began a sweep into the Basque country, and uncovered a knot of English 'heretics' at San Sebastián. In May of that year a young Fleming, and naturalised Englishman named John Tack was burned at Bilbao, the first foreign Protestant to be be executed by the Inquisition in Spain. ${ }^{16}$ In this climate an idealistic and impressionable young priest might well be encouraged to perceive England as a source of heretical contamination, or as a potential mission territory as much in need of true Catholic teachers as New Spain or Peru.

With the fate of Tack we have reversed the angle of vision, from the persecution of Spaniards holding what were regarded as unorthodox views in England, to the troubles of their English counterparts in Spain. This was not an isolated case. Throughout the late 1530s and early 1540s a growing number of the English merchants trading in Spanish towns were to have brushes with the Inquisition, both in the northern ports and in the other main field of English mercantile activity, the Andalusian coastline in the vicinity of Cadiz and Seville. Their accounts of their experiences, though undoubtedly sometimes partial and selective, offer important insights into how the religious policies of Henry VIII's government were perceived in one of England's near neighbours, and provide an illuminating backdrop to the stage on which the Henrician authorities sought to play out their own approved version of the nature and extent of religious reform in England.

English merchants in Spain were falling foul of the Inquisition as early as 1534, Thomas Cromwell raising the matter with the Imperial ambassador, Eustace Chapuys in October of that year, and again in February $1535 .{ }^{17}$ In July the scholar and diplomat John Mason reported to Thomas Starkey from Valladolid that two merchants who had brought with them 'a follishe booke agaynst the Pope' had been arrested and suffered confiscation of goods. They would have been burnt 'if we had not made for them great frinds and intreatance'. ${ }^{18}$ By the early 1540s, the treatment of English merchants in the Emperor's lands had become a serious diplomatic issue. In January 1540, Thomas Wyatt, Henry's ambassador in Paris, raised the matter of 'the evill handlyng that thei have there by the Inquisition' with Charles V himself during the latter's stay in France. Charles responded evasively, asserting that 'the auctoryte of the inquisition dependid not apon him', and that Englishmen trading in his domains must obey his laws. These protestations were somewhat disingenuous. The Emperor had already intervened to protect English merchants from the Inquisition early in

\footnotetext{
${ }^{16}$ Monter, Frontiers of Heresy, pp. 143-6; H. Kamen, The Spanish Inquisition: An Historical Revision (paperback edn., London, 1998), p. 100.

${ }^{17}$ LP, vii. 1297; viii. 189.

${ }^{18}$ H. Ellis (ed.), Original Letters illustrative of English History (2 ${ }^{\text {nd }}$ ser., 4 vols., London, 1827), ii. 59.
} 
1535, and was to do so again in January $1546 .{ }^{19}$ Wyatt himself claimed in 1541 that during his time as ambassador in Spain only Charles's personal intervention had kept him out of the clutches of the inquisitors for speaking against the bishop of Rome: 'th'emperore had myche a doe to save me' ${ }^{20}$ But the English remained distinctly unsatisfied with the King of Spain's efforts in this behalf. Henry VIII returned to the theme in a meeting with the Imperial ambassador, Van der Delft, in July 1545, complaining of seizures in Spain where 'his subjectes were denied a hearing and called heretics'. Such treatment, he warned, would no longer be tolerated. ${ }^{21}$ Without doubt, the intensity of the potential persecution English subjects faced in Spain was affected by the state of diplomatic relations between the Emperor and the English King. It was a tap that, to some extent, Charles could turn on and off to suit his diplomatic agenda. ${ }^{22}$ But the pressure in the system appears to have been an intense popular hostility to what was thought to be happening in England, a hostility fanned by and finding its institutional outlet in the activities of the Inquisition, but that was by no means confined to the officials and employees of that body.

In order to establish that this was actually the case, and to delineate some of the salient features of this popular hostility, it is necessary to need to look in more detail at the accounts sent home from Spain by Englishmen in the late 1530s and early 1540s. A recurrent feature of these is the suggestion that the Inquisition's predatory interest in the opinions of English merchants was fully supported by a wide swathe of the population with whom the English came into contact, something which seems to apply equally to the English presence in the Basque provinces and Cantabria in the north, and in Andalusia in the south-west. From the Basque port of Rentería in August 1537, Hugh Typton's advice was to keep social contacts with the Spanish to a minimum, 'for they have not orderyd oure nassyon well this yere'. ${ }^{23}$ This was the voice of experience: in July, Typton and another merchant, Thomas Shipman, had been put to public penance in San Sebastián for words against the pope and prayer to saints, and for saying that 'our kinge did make no lawes in England but that... did stand with godes lawes'. ${ }^{24}$ Another Englishman who learned the value of circumspection in his dealings with the locals was Thomas Pery, arrested by the Inquisition at Lepe on the Gulf of Cadiz in October 1539 after an argument with a priest over whether Henry VIII was a good Christian or a heretic. Pery was imprisoned in the Inquisition's headquarters in the castle of Triana on the outskirts of Seville, was put to torture, and after recanting and undergoing public penance was sentenced to six months' incarceration. ${ }^{25}$ Looking into the ill-treatment of Pery and other English merchants was part of the remit of Roger Basyng, a member of the royal household despatched to Spain to buy horses in the early summer of 1540. In Bilbao Basyng reported coming across 'dyvers spytefull persones that opprobryously speke against the kynges maiesty and his councell in the busshop of Romes favour... specially relygous personnes and preestes'. If they managed to get any Englishman on

\footnotetext{
${ }^{19}$ LP, viii. 327; C[alendar of] S[tate] P[apers], Spanish, ed. P. de Gayanagos et al (15 vols in 20, London, 1862-1954), viii. 185.

${ }^{20}$ K. Muir (ed.), Life and Letters of Sir Thomas Wyatt (Liverpool, 1963), pp. 204, 196.

${ }^{21} L P, \mathrm{xx}(1) .1087$.

${ }^{22}$ On this point, see Connell-Smith, Forerunners of Drake, pp. 101-2, 105, 122, 126.

${ }^{23}$ PRO, SP 1/123, fo. 217r (LP, xii (2). 443).

${ }^{24}$ PRO, SP 1/124, fo. 251r (LP, xii (2). 716 (2)).

${ }^{25}$ Pery supplied a full account of his experiences in letters sent from prison in Spain to Richard Field and Ralph Vane: B[ritish] L[ibrary], Cotton MS Vesp. C vii, fos 91v-95r, 102r-106r. The letter to Vane is printed, with some transcription errors, in Ellis, Original Letters, ii. 139-53; an account of Pery's tribulations is given by Connell-Smith, Forerunners of Drake, pp. 111-18.
} 
his own, they would seek to debate the pope's authority, hoping to 'take an advanntage of his wordes' and present him to the Inquisition. All those who had raised these matters with Basyng (who seems to have managed to remain circumspect in his replies) had insisted that 'the busshop of rome and his cardynalles be Ecclesiam Catholicam, and he that denyeth this, they say is an heretycke and worthy to be brunte'. ${ }^{26}$ In July, Basynge travelled south to San Lúcar to hold conference with a gathering of the 'ynglysh nacion' resident in Andalucia under their newly-elected governor, William Ostrych. Basyng presented them with a book of the complaints of Thomas Pery, and in reply they prepared a document confirming the veracity of Pery's story, and describing their own collective experience of the state of relations with their Spanish hosts. This matched Basyng's own observations in Bilbao. The inhabitants, both spiritual and temporal, would not desist 'dayly in all places' from vehemently dishonouring King Henry, affirming him to be 'an heretyke and lutheran'. Any Englishman defending his king was liable to be imprisoned with loss of goods and threats of death, and all merchants lived in fear of the Inquisition. Four or five English merchants were said still to be in the Inquisition's prison, and others currently in England dared not return to Spain. Repeatedly, the English in Andalusia emphasised the common people's extreme hostility towards them, and their support for the actions of the Inquisition. They 'have no other communicacion but demande us and every of us if his grace be retorned agayne to the faith and the opinion of hollie Churche... with such malicious and slanderous woordes that it is not to be wrytten'. The danger of being arrested for 'speking some worde in the honour of our... sovereign lorde' was such that 'we dare nott company nor comon with the naturalles of this cuntreth nor conacte with theym as in tyme past we have done'. ${ }^{27}$

While there may have been an element of playing to the gallery in the formalised complaint of the English merchants in Andalusia, the substance of their allegations is amply confirmed from other sources. Richard Abbis, who visited both Corunna and Cadiz in the late summer of 1538, judged himself well able to assess the 'favor bothe in worde and dede that this Spanyards... bare towardes the kynges grace and his subiectes'. His perception was that 'the Kynges subiecttes hathe her in all partis lyttel or no favor... thay all be takyn in derycion and hattyde as torkes and cawllyde eretykes and lutaryos'. ${ }^{28}$ Sir Thomas Wyatt, looking back in 1541 on his experiences as ambassador in Spain in 1538-9 similarly recalled 'the name that Inglysshe men then had to be all Lutherans'. ${ }^{29}$ That all were likely to be tarred with the same brush was discovered by Nicholas Lesse in the Galician port of Bayona in October 1539. A Spaniard there began to taunt him, saying that King Henry was 'a greatte favorar of heretykes' and that the whole realm was infected with the same vice. When Lesse reproached him, reasoning that 'on man or twayn myght offende not to condem a wholl realm', the Spaniard threatened him, saying 'that I was on off them'. ${ }^{30}$ This was not the only nor the most dramatic confrontation between Englishmen and Spaniards on the Atlantic coast in 1539. In February of that year fighting broke out in Lisbon between the crews of English and French ships anchored

\footnotetext{
${ }^{26}$ PRO, SP $1 / 160$, fo. $152 \mathrm{r}(L P, \mathrm{xV} .787)$.

${ }^{27}$ PRO, SP 1/161, fos 65r-67r (LP, xv. 859); Connell-Smith, Forerunners of Drake, pp. 118-21.

${ }^{28}$ BL, Cotton MS Vesp. C vii, fo. 87r (LP, xiii (2). 429).

${ }^{29}$ Life and Letters of Sir Thomas Wyatt, 204.

${ }^{30}$ PRO, SP 1/155, 99r-v (LP xiv (2). 659).
} 
in the harbour there. Despite their recent history of national hostilites with France, the 'Biscayans' present pitched in against the English until local officials restored order. ${ }^{31}$

There is an obvious danger here of painting too monochrome a picture of English experiences in Spain in the years after Henry VIII's break with Rome. After all, English merchants remained in Spain, and Anglo-Spanish trade continued throughout the period. It is also legitimate to question whether all Spaniards were really filled with righteous indignation against England and all things English. At a high-point of international tension between England and Spain in January 1539, a letter from William Ostrych could make mention of 'our friends here' who were giving 'secret warning to take care of our goods' as they foresaw the approach of war. ${ }^{32}$ It would also be possible to argue that the narratives in which English merchants retailed their sufferings at the hands of inquisitors and an inscrutably hostile population can be seen to exhibit, like so many other documentary records of the period, distinctly 'fictive' qualities, in which themes of simple patriotism and guileless victimhood are consciously fashioned. Nonetheless, the multiplication of such reports does appear to provide clear evidence of the existence, if not of an unproblematically hostile 'public opinion', at least of a prevalent 'public discourse', in terms of which it was increasingly legitimate to regard the English ipso facto as tainted with heresy. Moreover, these reports are echoed by evidence coming from areas outside the Iberian peninsula. In October 1538, for example, Cromwell's agent Thomas Theobald was reporting from Padua that 'they have made here a wonderous matter and reporte off the shryne and bornyng of the Idols bournt at Canterberye', and that it was believed the king and his council were become sacramentarians, on account of overtures to Henry from the Elector of Saxony. ${ }^{33}$ In November the same year Henry's ambassadors in Brussels were challenged over dinner that 'religion was extinct in Englande'. ${ }^{34}$ The following year Lord Lisle complained that the religious controversies in Calais had led 'universally in all parts overseas, as France and Flanders and other exterior parts, to run into great slanders', endangering all the king's subjects. As evidence that 'the people of the said exterior parts have conceived very evil opinions towards our nation', he cited a recent case in Picardy, where a priest refused to begin mass when he saw an Englishman in the church. The rest of the congregation 'plucked him out of the church and churchyard by the ears'. In the village of Marguison, the people had refused burial in the churchyard to an Englishman's child being nursed there. ${ }^{35}$ Writing to the Duke of Norfolk from Bruges in July 1540, Richard Pate reported claims being made locally that 'all pietie and religion having no place was banished owte of Inglande'. ${ }^{36}$ In the same letter of 2 September 1541 in which the Council reported the continued obstinancy of Pedro Ladron, reference was made to an enclosed letter of complaint from certain English merchants 'by the which letter you shall perceve how unkyndely Englishmen be delt withall by the Frenchmen'. ${ }^{37}$ That Englishmen could plausibly be portrayed as the archetypal purveyors of heresy is suggested by an incident in Lisbon in the first weeks

\footnotetext{
${ }^{31}$ CSP, Spanish, vi (1). 109. Religious sympathies were probably reinforced by the fact that the French were heavily outnumbered, and had taken up the cry 'Empire! Empire!'.

${ }^{32} L P$, xiv (1). 158.

${ }^{33}$ H. Ellis (ed.) Original Letters Illustrative of English History (11 vols in 3 series, London, 1824-6), III, iii. 128. The Italians Theobald spoke to clearly had a shaky grasp of Lutheran eucharistic theology. ${ }^{34}$ PRO, SP $1 / 139$, fo. $164 \mathrm{v}$ ( $L P$, xiii (2). 880).

${ }^{35}$ M St. Clare Byrne (ed.), The Lisle Letters (6 vols., London and Chicago, 1981), v. 553.

${ }^{36}$ PRO, SP 1/161, fo. 87r (LP, xv. 876). Pate affirmed, however, that since the fall of Cromwell, and in the light of his own assurances, such misconceptions had abated.

${ }^{37}$ PRO, SP $1 / 167$, fo. 16 r (LP, xvi. 1141).
} 
of 1539. The Imperial ambassador there, Luis Sarmiento de Mendoza, reported to Mary of Hungary, governor of the Netherlands, that placards had been placed in churches containing 'the most detestable heresies that could be imagined'. Mendoza thought the culprit most likely to be some 'literary Jew', but the placards had appeared with a quatrain under them stating that 'all inquiries would be vain and fruitless, as the placards were the work, not of a Castilian, French, Italian or Portuguese subject, but of an Englishmen'. The claim was clearly designed to be plausible, as well as to maximise offence with its assertions of impunity. Predictably, Mendoza commented that 'all this proceeds from there not being in Portugal a Holy Inquisition'. ${ }^{38}$

In all of this an obvious and significant irony becomes apparent. A great many of the cases cited above in which foreigners, Spaniards above all, seem to perceive England as a hub of heretical depravity coincide exactly with the period when, in the view of many historians, the Henrician Reformation was entering its most conservative phase. In November 1538, according to one influential recent account, 'Henry VIII stopped the Reformation dead. ${ }^{39}$ The following year saw the passing of the Act of Six Articles, which reaffirmed transubstantiation, private masses, communion in one kind, vows and clerical celibacy, and auricular confession. In 1543 the King's Book ruled firmly against justification by faith, and an 'act for the advancement of true religion' placed severe restrictions on access to vernacular scripture. Historians of the Henrician Reformation remain divided about how 'conservative' the 1540s actually were $^{40}$, but one thing is beyond dispute. This was a period when Henry was desperate to vindicate his orthodoxy to the outside world, to project an image of himself as a 'christian, Catholic prince'. ${ }^{41}$ No doubt this was how the king genuinely saw himself, but questions of policy had a part to play as well. In the late 1530s Henry had been haunted by the prospect of a General Council convening under papal auspices, and had also been severely rattled by the brief Franco-Imperial entente inaugurated by the Truce of Nice in June 1538. ${ }^{42}$ A draft treatise of 1539, headed 'A sumarie declaration of the feith uses and observacions in England', and clearly intended for an overseas audience, provides an intriguing insight into the Henrician Reformation as the King and his advisors wanted others to see it. ${ }^{43}$ The text began dramatically with the claim that 'Englishmen have forsaken Satan his satellites and all workes of darkenes', and

\footnotetext{
${ }^{38}$ CSP, Spanish, vi (1). 109-10.

${ }^{39}$ C. Haigh, English Reformations: Religion, Politics, and Society under the Tudors (Oxford, 1993), p. 152. The crucial indicators here are said to be Henry's proclamation against heresy of that month, and the trial of the sacramentarian, John Lambert. Haigh's chapter on the 1540s is entitled 'Reformation Reversed'.

${ }^{40}$ For suggestions that official policy in the 1540s remained radical in significant respects, see D. MacCulloch, 'Henry VIII and the Reform of the Church', in idem (ed.), The Reign of Henry VIII: Politics, Policy and Piety (Basingstoke, 1995), pp. 176-7; G. W. Bernard, 'The Making of Religious Policy, 1533-1546: Henry VIII and the Search for the Middle Way’, Historical Journal, xli, 2 (1998), 321-49.

${ }^{41}$ In the 1530s members of the government seem to have made a point of describing their master in these terms in conversations with the Imperial ambassador: $L P$, vi. 465; vii. 1257; viii. 666.

${ }^{42}$ See P. Marshall, 'Papist as Heretic: the Burning of John Forest, 1538', Historical Journal, xli, 2 (1998), 359-61, 371-3.

${ }^{43}$ PRO, SP 1/143, fos 198-206 (LP, xiv (1). 402). The document is discussed by G. R. Elton, Policy and Police: the Enforcement of the Reformation in the Age of Thomas Cromwell (Cambridge, 1972), pp. 195-8, where the hand is identified as that of Thomas Derby, clerk of the Privy Council, evidence of the treatise's 'official' status.
} 
proceeded to itemize what 'Englishmen' believed, including a resounding assertion of the fundamental Catholic orthodoxy of Henry’s church and nation:

Englishemen deteste the anabatistes [sacramentaries and all other heresies] and with grete reverence do solempnise holy baptism, the sacrament of the blessed body and blud of Christ and other sacramentes and sacramentalls as they have done in tymes passed with all the laudable ceremonys and [dayly] masses, and do the [other] service of god in their churches as honourably and devotely [paye tythes and offeringes truly] as ever they did and [as any men] do in any part of christendom. ${ }^{44}$

This was the line Henry expected his ambassadors abroad to pursue on every available opportunity. The instructions the King drafted for Ralph Sadler on his departure to Scotland in February 1540 emphasized the importance of ensuring that James $\mathrm{V}$ was not deceived by 'persuasion of untrue and fayned tales', and was not to think of him 'otherwise than of every christen and catholique prince as he is in dede'. ${ }^{45}$ In his conversation with the Emperor in January 1540, Thomas Wyatt argued the unreasonableness of the Inquisition's pursuit of English merchants on the grounds that Henry 'concurrid and agreid with all notable ceremonys usid in the cyrche with punishmentes of heresis, as Sacramentarys, Anabaptistes and other'. 'The difference alone', he suggested, 'was but abowt the bishopp of Rome'. ${ }^{46}$ It was a source of considerable irritation to the English authorities that the Spanish seemed incapable of grasping that (putting aside England's more enlightened attitude towards the papacy) the two nations shared the same faith. The distinct asymmetry of treatment experienced by Henry's subjects in Spain, and Charles's subjects in England was an issue featuring prominently in the instructions given to Wyatt's successor, John Mason, on his departure for Spain late in 1540. Mason was to threaten to 'rendre the semblable' if Englishmen continued to be 'most extreamely, rigorouslye and iniustlyye handled there'. ${ }^{47}$ On an earlier occasion, complaining to Chapuys about the ill-treatment of Englishmen by the Inquisition, Thomas Cromwell made the aggrieved protestation that 'if they had been convicted of real heresy, the king and his council would have been glad that they had been burned'. ${ }^{48}$

The definition of 'real heresy' is of course the very point at issue, and Cromwell was begging some pretty big questions. Nonetheless, a significant and long-standing strand of historiographical opinion has tended to vindicate the line advanced by Wyatt and Cromwell in their diplomatic roles, and to view the religious settlement enforced by Henry VIII as a kind of 'Catholicism without the pope'. In this approach, emphasis is laid on Henry's determination to retain the sacramental structure of traditional Catholicism, particularly the mass, with a concomitant tendency, either implicitly or explicitly, to interpret such striking features of the Henrician Reformation as the destruction of shrines and images, and the dissolution of

\footnotetext{
${ }^{44} \mathrm{PRO}, \mathrm{SP} 1 / 143$, fo. 198r (interlineations in square brackets).

${ }^{45} \mathrm{BL}$, Cotton MS Calig. B i, fos 59v, 62v-63r (LP, xii (1). 1313).

${ }^{46}$ Life and Letters of Sir Thomas Wyatt, 124.

${ }^{47}$ PRO, SP 1/164, fos 53r-v (LP, xvi. 354).

${ }^{48} L P$, viii. 189. It does seem to be the case that most of the English merchants troubled by the Inquisition in 1534-46 were arrested for espousing views which would not have been considered heretical at home. Of course, in their letters of complaint to contacts and patrons in England, the victims had a vested interest in stressing that their 'crimes' amounted to no more than defending the ecclesiastical policies of their sovereign.
} 
monasteries as essentially marginal to the preservation of 'Catholicism' in England. ${ }^{49}$ The Royal Supremacy itself is classified as a jurisdictional rather than doctrinal matter. ${ }^{50}$ Other historians, some writing from within the Catholic tradition, have not agreed, arguing that by severing links with the papacy, the Ecclesia Anglicana disqualified itself from membership of the universal Catholic Church - in contemporary terms, the view of Thomas More rather than Thomas Wyatt. ${ }^{51}$

Yet a criticism that can be made of all sides in this long-running controversy is that they have tended to reify a construct that is by definition highly unstable, contingent, and contested. Orthodoxy, like beauty, resides in the eye of the beholder, and judgements as to whether or not the Henrician Church was really 'Catholic' are the business of theologians not historians. ${ }^{52}$ To Pedro Ladron, it is quite clear that the papal supremacy was not a matter of church government, but a crucial issue touching the faith. In this, he was by no means unsual. The priest who clashed with Thomas Pery in Ayamonte thought Henry VIII a heretic because he would be 'pope within hym selfe in his Reyme, ${ }^{53}$, and as we have seen, it was over the issue of the royal supremacy that the citizens of Bilbao seemed to want to pick fights with Roger Basyng in June 1540. In October 1538, Cromwell's correspondent in Seville, Richard Abbis, bemoaned that 'all our nashon her is abhoryde and saythe wee be erytykes, and is bycawsethe kynges grace wryttes in his tytull as most worthy suprym hed of the church'. Indeed, Spanish courts would admit no documents bearing the title, which had made it impossible for one Mr Rochis to recover 12,000 ducats from the executors of Thomas Howell bequeathed to the Drapers' Hall. ${ }^{54}$ This legal barrier was to be a recurrent irritant. In July 1536, Henry himself had raised it with the Imperial ambassador, complaining of the imprisonment of one of his subjects for exhibiting in judgement 'a certain power' naming the king as supreme head. It was an issue about which Henry understandably had strong feelings: 'he knew not what injury could be greater than to take away from him that title and prerogative which God and reason had given him. ${ }^{55}$ Chapuys promised to write to the Emperor about it, but Spanish prickliness about the issue showed no signs of abating. In June 1545 reports were being forwarded to Paget that English merchants 'ar not only very moche empeched in Spayn by thinquisitors but also somtyme in other courtes repelled from pursuing their right as persons excommunicate and heretikes, in the whiche the kinges majestie is also named'. ${ }^{56}$ Meanwhile, the matter of the King's title continued to bedevil

\footnotetext{
${ }^{49}$ See, for example, A. F. Pollard, Henry VIII (London, 1902), pp. 310-11; G. Constant, The Reformation in England: I The English Schism, tr. R. E. Scantlebury (New York, 1934), pp. 430-35; H. M. Smith, Henry VIII and the Reformation (London, 1948), pp. 167, 452, and more recently, G. Redworth, In Defence of the Church Catholic: The Life of Stephen Gardiner (Oxford, 1990), pp. $48-9$. ${ }^{50}$ Connell-Smith, for example, comments that in Henry's reign 'the religious question... was clearly not yet one of doctrine' and that 'the religious quarrel at this stage was political rather than doctrinal': Forerunners of Drake, pp. 107, 198.

${ }^{51}$ E. C. Messenger, The Reformation, the Mass and the Priesthood (2 vols., London, 1936-7), i. vi, 240; P. Hughes, The Reformation in England (3 vols., London, 1950-54), i. 197, 217, 278, 360; J. J. Scarisbrick, Henry VIII (London, 1968), p. 399; P. O’Grady, Henry VIII and the Conforming Catholics (Collegeville, MN, 1990), pp. 10, 122; R. Rex, Henry VIII and the English Reformation (Basingstoke, 1993), pp. 171-2.

${ }^{52}$ I intend to explore these issues further in a forthcoming article 'Is the Pope a Catholic? Henry VIII and the Semantics of Schism', in E. H. Shagan and M. Senna (eds.), Catholics and the Protestant Nation: English Catholicism in Context 1534-1640.

${ }^{53}$ BL, Cotton MS Vesp. C vii, fo. 102r.

${ }^{54}$ PRO, SP 1/137, fo. 244r (LP, xiii (2). 660).

${ }^{55} L P$, xi. 40.

${ }^{56}$ PRO, SP $1 / 202$, fo. 105 r (LP, xx (1). 981).
} 
Anglo-Imperial relations at the highest level. In early 1543 plans for an anti-French alliance were immensely complicated by Charles's refusal to sign any treaty according Henry the style of Supreme Head, and Henry's determination not to concede on the issue, an impasse only broken by an implicit agreement by both sides to read what they wished into the form 'Defender of the Faith, etc.' ${ }^{57}$

Along with the royal supremacy, the issues that seem to have resonated most with foreign observers, and to have provided for them the most compelling evidence of England's slide into heresy, were the actions taken in the Henrician campaign against 'superstition' - the treatment of images, relics, shrines and monasteries. This was explicitly recognised by the 1539 'Declaration of the feith' which while presenting the King's crackdown on various aspects of traditional religion as godly and justified, admitted that 'calumnators do diffame and slaunder the nation thereby, sayng that Inglyshmen have put down the christen Religion, churches, holy dayes, pardons, images and brent holy saintes and reliques'. ${ }^{58}$ This was precisely what some were saying in Brussels in 1538. Henry's ambassadors there reported meeting with a nobleman who told them 'it was thought in thise partyes of many... that saintes were burned, and al that was taken for holye clerely subverted'. ${ }^{59}$ Among the 'slanders and obloquies' Richard Pate had been hearing in Bruges were claims that 'we nother observed holydays nor regarded sainctes as we had, none of there images stonding within our churches', that the English 'no more fasted then dogges, the lent abrogated' ${ }^{60}$ These motifs are particularly prominent in the encounters Englishmen reported with Spanish critics. To the Spaniard who berated Nicholas Lesse at Bayona in October 1539, the clinching evidence that Englishmen 'were all heretykes' was the fact of their king having 'cast forthe off all hys chyrches all manner off ymages' ${ }^{61}$ Particularly revealing in this respect is the case of Thomas Pery, already referred to. Here the catalyst for the quarrel with a local priest, and the subsequent preferal of heresy charges by the Inquisition was the priest's detection in Pery's warehouse in Ayamonte near Seville of a large brass bell, which a colleague of Pery's had imported and intended to sell. Rightly or not, the priest clearly believed the bell to be spoil from a dissolved religious house, provoking the outburst: 'what a goode Crysten is yowre Kinge of Ynglande to pute downe the monesterys and to take a waye the belles'. In the event unwisely, Pery responded to the provocation, challenging 'that if yowe thinke that he be not a goode crystyane go yowe thyther and showe his grace so'. The priest, in this repect clearly a more cautious individual than Pedro Ladron, answered 'that he had neyde to have more helpe' to undertake such an endeavour, and after further exchange of words he hurried off to delate Pery to the Inquisition. Later when the inquisitors demanded what evidence he had for his claim that Henry VIII was a good Christian, Pery made answer in terms which the king himself would surely have applauded:

hys grace hathe cawssyde openly to be proclaymyde throwe owt his Reyme commandyng all hys trew and feythefwll subgettes to upserwe and keype all manner of holly sacrementes and sacrementaws, and all holly serwes to be sownge and saide in all paryschyre [parishes] and chyrchis throwe owit his Reyme, to the oner and glory of gode, and that hys grace hym selfe dowthe

\footnotetext{
${ }^{57}$ Scarisbrick, Henry VIII, pp. 439-40.

${ }^{58}$ PRO, SP 1/143, fo. 202r.

${ }^{59}$ PRO, SP $1 / 139$, fo. $164 \mathrm{v}$ ( $L P$, xiii (2). 880).

${ }^{60}$ PRO, SP 1/161, fo. 87r (LP, xv. 876).

${ }^{61}$ PRO, SP 1/155, do. 99r (LP, xiv (2). 659).
} 
dayly here masse and serwe gode within hys owyne chappell whiche is within his owne manner, and confessyth hym selfe, and recewithe hys maker yerlye acording to the lawdebull usse and costom of our holy mother churche, and so commandythe all hys subgettes to do the same apone payne of deythe, and also to keype the yemberinge fastys and all other fasting dayes acording to the olde ansyent costome.

This eloquent assertion of English religious practice as el catolicismo sin el papa was substantially that which Wyatt would proffer to Charles V in Paris early the next year, but it made little impression on the Seville Inquisition. Repeatedly, Pery was pressed on whether he had said and believed that the King did well to put down monasteries and take away bells, and eventually under torture he admitted he had done so. The judge in the case, Pero Diez, was anxious that Pery should understand the true character of his sovereign, and his words, assuming Pery reported them accurately, provide a revealing sketch of the Henry VIII inhabiting the imaginations of middleranking Spanish clergy: 'abowit x or xii yere a gone your kyng wrytte a gaynste Lwtther that greyt erytycke, and no crysten kynge so myche as he, and nowe he is the gretteste erytycke in the worlde, and yf we had hym heyere we wolde brone hym, all the world showlde not sawe hym'. He was, moreover, 'a wery tyranitte, and a man qwyller... and spendithe hys tyme in all vysshwsness, and in howntyng and halkynge'. Having forsaken his lawful wife, he took another 'and lewyde with hir in a vowtery; and within shorte space after he cawssid hir heyde to be stroken of ' ${ }^{62}$ Pery's misfortunes were a cause célèbre, but he was not the only Englishman for whom the dissolution of the monasteries created severe difficulties. According to the English merchants assembled at San Lúcar in July 1540, it was the usual procedure of the Inquisition to demand of English suspects 'yf they thynke the kinge doo well to pulle downe Abbays and Monasteryes and to put the relligious men to deth' ${ }^{63}$ The fall of the monasteries also dogged the progress of Henry’s envoy, Roger Basyng, who was closely monitoring the fate of Pery and other English prisoners. From Seville in August 1540 he reported he had been arrested for debt at the suit of a certain Frenchman, who then accused him of being a Lutheran, solely on the grounds that he had been granted the farm of an abbey by Henry, 'thynkyng thereby to have the mor favour and advantage against me'. ${ }^{64}$ As we have seen, a horror at the fate of religious houses played a significant part in Pedro Ladron's indictment of religious policy in England.

In fact, it is now possible to acknowledge that the views espoused by Pedro Ladron before Bishop Salcott and Archbishop Cranmer in 1541 - that Henry's repudiation of the pope was a departure from the faith, that the putting down of monasteries was a scandal - seem fairly typical of what many Spanish clerics and laypeople were thinking and saying in the late 1530s and 1540s. The emergence of forms of mutual hostility - political, cultural, and religious - between England and Spain in the

\footnotetext{
${ }^{62}$ BL, Cotton MS Vesp. C vii, fos 102r, 104r, 105v. It is perhaps surprising that remarks of the kind attributed to Diez about Henry's repudiation of Catherine of Aragon, and his subsequently lurid matrimonial life, do not figure more prominently in the reports coming back from Spain. It is possible that English correspondents

may have filtered out this topos from their accounts of what Spaniards were saying as too sensitive to be directly alluded to.

${ }^{63}$ PRO, SP 1/161, fo. 66v (LP, xV. 859).

${ }^{64}$ PRO, SP 1/162, fo. 62r (LP, xv. 977); SP 1/164, fo. 53r (LP, xvi. 354).
} 
sixteenth century is not, of course, a new topic. But historians have shown decidedly more interest in how the English came to perceive the Spanish than in the obverse of the relationship. We have become familiar with the 'Black Legend' of Spanish cruelty and fanaticism as it developed in England after the reign of Mary Tudor ${ }^{65}$, but arguably not enough attention has been paid to the formation of an 'English Black Legend' taking shape in Catholic Europe, particularly in Spain, in the reign of Henry VIII. The English king, who regarded himself as a paragon of Catholic orthodoxy, and wished the rest of Europe to see him in the same light, appears to have been widely represented in Spain as a ruthless iconoclast, a barbaric traducer of sacred places and sanctified things, a slaughterer of holy and sanctified persons. ${ }^{66}$ The judgement of the evangelically-minded dean of Exeter, Simon Heynes, in May 1539 that Henry was 'cownted in all the world a christen catholik prince' was wishful thinking of the highest order. 67

The significance of this for religious and cultural developments within Spain is worth reflecting upon, if an historian of Tudor England may be permitted briefly so to do. The failure of the Reformation in Spain is a familiar historical theme: a short trajectory from the beginning of moves against Erasmian alumbrados in the 1520s to the spectacular series of autos-da-fé in Valladolid and Seville which eradicated the small pockets of indigenous Protestantism in 1558-62. ${ }^{68}$ Nonetheless, historians of the Inquisition have consistently recognized the importance of a supposed 'Lutheran' threat in revitalising an institution which by the early decades of the sixteenth century had been left without much of a raison d'être by virtue of the very success of its campaigns against conversos and 'judaisers'. The number of actual sympathisers with the Reformation in Spain may have been extremely small, but the Inquisition enjoyed considerable success in mobilizing, or even creating popular concerns about Protestant heresy. ${ }^{69}$ Thus, in later sixteenth-century Spain, the 'Lutheran' became 'a bogeyman to be raised against all forms of dissent quite unconnected with genuine Protestantism', 'a permanent spectre... which was made to "collaborate” in the task of stabilising a feudal, aristocratic and authoritarian social order'. ${ }^{70}$ The fact that some Spaniards seem to have regarded inglés and luterano as virtually interchangable terms, strengthens the case for this being seen as a discursive strategy already firmly underway in the 1530s and 1540s. These, J. H. Elliott has argued, were crucial

\footnotetext{
${ }^{65}$ W. S. Maltby, The Black Legend in England: The Development of Anti-Spanish Sentiment, 15581660 (Durham, NC, 1971). See also C. Gibson (ed.), The Black Legend. Anti-Spanish Attitudes in the Old World and the New (New York, 1971).

${ }^{66}$ Conceivably, the horror that Henry's iconoclastic actions seem to have aroused was a reflection of the centrality to contemporary Spanish religious culture of shrines, relics and a general sense for the embodiment of the sacred, as documented by W. A Christian in his Local Religion in Sixteenth-Century Spain (Princeton, NJ, 1981). How uniquely Spanish these instincts were, however, is another question. Images and localised saint-cults were certainly a crucial part of pre-Reformation English religious life. See E. Duffy, The Stripping of the Altars: Traditional Religion in England 1400-1580 (New Haven and London, 1992).

${ }^{67}$ BL, Cotton MS Cleo. E v, fo. 60v (LP, xiv (1). 1055).

${ }^{68}$ Good short recent surveys are A. Gordon Kinder, 'Spain', in A. Pettegree (ed.), The Early Reformation in Europe (Cambridge, 1992), pp. 215-37; H. Kamen, 'Spain’, in B. Scribner, R. Porter and M. Teich (eds), The Reformation in National Context (Cambridge, 1994), pp. 202-14.

${ }^{69}$ S. T. Nalle, God in La Mancha: Religious Reform and the People of Cuenca, 1500-1650 (Baltimore and London, 1992), pp. 32-4, 56-7; S. Haliczer, Inquisition and Society in the Kingdom of Valencia 1478-1834 (Berkeley, Los Angeles and Oxford, 1990), pp. 293-4; J. Contreras, 'The Impact of Protestantism in Spain, 1520-1600', in S. Haliczer (ed. and tr.), Inquisition and Society in Early Modern Europe (London and Sydney, 1987), pp. 47-63.

${ }^{70}$ Kinder, 'Spain’, p. 229; Contreras, 'Impact of Protestantism’, p. 62.
} 
decades in the development of the Spanish Inquisition, the period when it transformed itself into 'a great apparatus operating through delation and denunciation'. He suggests also that it was about this time that most Spaniards were coming to consider the Holy Office as 'a necessary protection'. ${ }^{71}$ Historians of early modern Spain often recognize the nationalistic, indeed xenophobic impulses that ran through the institutions and the culture of the Spanish Counter-Reformation ${ }^{72}$, but none to my knowledge has drawn particular attention to the processes by which England, a traditional ally and trading partner, seems to have come to represent a dire moral warning, an exemplar of national apostacy. Though clearly by no means a sole or sufficient explanation, it can be suggested that the growing identification of England with a heretical/Lutheran 'other' played a noticeable role in firming up that commitment to absolute ideological purity characteristic of Habsburg Spain - what one historian of Spanish Catholicism has described as "the development of a strong sense of mission, and even an explicit "chosen people" complex, among Spanish leaders and spokesmen and apparently many of the common people as well. ${ }^{73}$

Pedro Ladron exemplified these trends in an advanced but not, I would suggest, abnormal or pathological form. A couple of years before Ladron set sail, Richard Abbis had found many in Cadiz who 'say here playnly that they trust shortly to have war with ynglande, and to set in the byshop of Rome with all his dyssypuls agayn in yngland'. ${ }^{74}$ A couple of years after his arrest, Henry's ambassador in Spain was warning that 'dyverse naughtie freers in Sevill' planned to poison the English king by sending over as a gift 'dyverse costelye boxes of marmelado' ${ }^{75}$ To understand fully the ways in which news about (and hostile views of) events in England were diffused and disseminated in mid sixteenth-century Spain would require considerable further research, but the pulpit must have been a crucial medium: the peninsula in the early 1540s seemed to be full of preachers who, as Wyatt protested to the Emperor, 'diffame the kyng and the nation and provok your subiectes agaynst the kinges'. ${ }^{76}$ In this context, Ladron's mission might seem more like an overly enthusiastic response to a prevailing national mood, than a bizarre aberration. Recent work on other early modern 'fanatics' has made the point that it is often more helpful to explore them as figures who act as channels for discourses and experiences latent within the networks from which they emerge, rather than merely to dismiss them as alien outsiders. ${ }^{77}$ Furthermore, there is a natural tendency to regard as fanatics only those who were ultimately unsuccesssful in their aims. After all, Ladron arrived in

\footnotetext{
${ }^{71}$ J. H. Elliott, Imperial Spain 1469-1716 (paperback edn., Harmondsworth, 1970), p. 218. Contreras agrees in identifying the 1540s as a turning point in the development of 'religious intransigence': 'Impact of Protestantism', p. 52.

${ }^{72}$ Kamen, Spanish Inquisition, p. 100; Nalle, God in La Mancha, p. 208; Contreras, 'Impact of Protestantism', pp. 53, 61: 'The foreigner was always a potential enemy because it was alleged that his very nature inclined him towards heresy’.

${ }^{73}$ S. G. Payne, Spanish Catholicism: An Historical Overview (Madison, WI, 1984), p. 45.

${ }^{74}$ BL, Cotton MS Vesp. C vii, fo. 87r (LP, xiii (2). 429).

${ }^{75}$ PRO, SP 1/176, fo. 91v (LP, xviii. 231 (1)).

${ }^{76}$ Life and Letters of Sir Thomas Wyatt, pp. 123-6. It seems likely also that the Inquisition's 'Edict of Faith', which was proclaimed annually in Lent in cathedrals and other churches, had a role to play here. From the early 1530s, denunciations of 'Lutheranism' were added to the traditional descriptions of Jewish and Islamic 'heresies': Haliczer, Inquisition and Society in Valencia, pp. 293-4; H. C. Lea, A History of the Inquisition of Spain (4 vols., New York, 1906-7), ii. 91-101; iii. 422.

${ }^{77}$ See particularly A. Walsham, “"Frantick Hacket”: Prophecy, Sorcery, Insanity, and the Elizabethan Puritan Movement', Historical Journal, xli, 1 (1998), 27-66. I have also benefitted from remarks on the Catholic would-be assassin of Elizabeth I, John Somerville, in a paper given by Richard Wilson at the colloquium on 'Shakespeare and the Warwickshire Catholic World', Stratford-on-Avon, 19 Sep. 1998.
} 
England only a year after the formal ratification by the Pope of a new religious order founded by another religious enthusiast from northern Spain's Atlantic coast, the members of which were to play a significant role in attempts to win England back to the 'true faith' in a subsequent generation. ${ }^{78}$ Ladron was no Ignatius Loyola, and his experiences in England in the summer of 1541 were undoubtedly a folie de grandeur. But they can also be seen as a microcosmic encounter between the religious sensibilities of Spain on the cusp of the Counter-Reformation, and England in the throes of that highly ambiguous construction, the Henrician Reform, a prelude to decades, if not centuries, of mutual mistrust and misunderstanding to come.

\footnotetext{
${ }^{78}$ It is worth noting here that one of Ignatius's early companions (and first biographer), Pedro de Ribadeneira, who entered the Society in August 1540, and who was on the brink of spearheading a Jesuit mission to England in Mary's reign, went on in later life to compose what became for Spaniards the standard (hostile) account of the English Reformation: Historia ecclesiastica del scisma del reyno de Inglaterra (Madrid, 1588). See J. W. O’Malley, The First Jesuits (Cambridge, MA, 1993), p. 36; T. M. McCoog, The Society of Jesus in Ireland, Scotland, and England 1541-1588 (Leiden, 1996), pp. 343-8.
} 
